\title{
АКТУАЛЬНІ ПРОБЛЕМИ ПІДГОТОВКИ МАЙБУТНІХ УЧИТЕЛІВ ПОЧАТКОВОЇ ШКОЛИ ДО ОРГАНІЗАЦІЇ ІНТЕРАКТИВНОЇ НАВЧАЛЬНОЇ ВЗАЕМОДІЇ УЧНІВ
}

\begin{abstract}
У статті розглянуто реальний стан підготовки майбутніх учителів початкової школи до організаиї інтерактивної навчальної взаємодї учнів, висвітлено його актуальні проблеми у системі вищої педагогічної освіти.

3'ясовано, щчо сучасні тендениії розвитку українського суспільства вимагають радикальних змін у підготовичі нового покоління педагогічних кадрів, зокрема майбутніх учителів початкової школи, де визначна роль відводиться проблемі формування компетентних фахівців, які орієнтуються у сучасних реаліях і перспективах, підготовлені до життя в постійно змінюваному, конкурентному, взаємозалежному світі. Головними завданнями реформування системи вищої педагогічної освіти України є усвідомлення майбутніми вчителями значущості суб' єкт-суб'єктних відносин у межах нової освітньої парадигми, побудованої на гуманістичних і демократичних засадах, иіннісною основою яких виступає інтерактивна навчальна взаємодія всіх учасників освітнього прочесу. Також вони мають бути професійно зорієнтованими на перебудову та оновлення змісту, форм і методів організації освітнього процесу в початковій школі відповідно до масштабності реформування иієї сфери.

Зроблено детальний аналіз ресурсного забезпечення підготовки здобувачів першого (бакалаврського) рівня вищої освіти спеціальності 013 «Початкова освіта». Висвітлено переваги та доцільність його використання у закладах вищої освіти Украӥни в умовах модернізації світового освітнього простору. Наголошено на важливості впровадження в практиці закладів вищої освіти основних положень про підготовку майбутніх учителів початкової школи до організачії інтерактивної навчальної взаємодії учнів.

Загалом, вивчення стану підготовки майбутніх учителів початкової школи до організачї інтерактивної навчальної взаємодії учнів дало змогу констатувати необхідність оновлення цฺього прочесу, щуо забезпечить формування відповідної готовності.
\end{abstract}

Ключові слова: вища педагогічна освіта, актуальні проблеми підготовки майбутніх учителів початкової школи, організація інтерактивної навчальної взаємодії учнів, учасники освітнього процесу, ресурсне забезпечення.

Kristina PETRYK, orcid.org/0000-0003-0615-5217 Candidate of Pedagogical Science,

Senior Lecturer at the Department of Primary Education of the Faculty of Psychological and Pedagogical Education and Arts Berdyansk State Pedagogical University (Berdyansk, Zaporizhzhya region, Ukraine)pertykk1510@ukr.net

\section{ACTUAL PROBLEMS OF PREPARING OF FUTURE PRIMARY SCHOOL TEACHERS FOR THE ORGANIZATION OF INTERACTIVE EDUCATIONAL CO-OPERATION OF STUDENTS}

The article considers the real state of preparing of future primary school teachers for the organization of interactive educational co-operation of students, highlights its current problems in the system of higher pedagogical education.

It was found that current trends in Ukrainian society require radical changes in the training of a new generation of teachers, including future primary school teachers, where a significant role is given to the formation of competent professionals, who are orient in modern realities and prospects, prepared for life in a constantly changing, competitive, interdependent world. The main tasks of reforming the system of higher pedagogical education in Ukraine are the awareness of future teachers of the importance of subject-subject relations within the new educational paradigm, built on humanistic and democratic principles, the value basis of which is interactive learning interaction of all participants. They should also be professionally focused on restructuring and updating the content, forms and methods of organizing the educational process in primary school in accordance with the scale of reform in this area. 
The made a detailed analysis of the resource provision of training of applicants for the first (bachelor's) level of higher education in the specialty 013 "Primary education". The advantages and expediency of its use in higher education institutions of Ukraine in the conditions of modernization of the world educational space are highlighted. Emphasis is placed on the importance of implementing in the practice of higher education institutions the basic provisions on the preparation of future primary school teachers for the organization of interactive educational interaction of students.

In general, the study of the state of preparing of future primary school teachers for the organization of interactive educational interaction of students allowed to state the need to update this process, which will ensure the formation of appropriate readiness.

Key words: higher pedagogical education, actual problems of preparing of future primary school teachers, organization of interactive educational interaction of students, participants in the educational process, resource provision.

Постановка проблеми. Динамічний темп розвитку всіх сфер суспільства, інтеграція до світового освітнього простору зумовлює оновлення змісту вищої педагогічної освіти. В умовах упровадження ідей Концепції «Нова українська школа» освітянська спільнота отримала творчі модернізаційні виклики, за яких видозмінюється місія педагога в контексті європейського професіоналізму зі збереженням кращих українських традицій. Сьогодення вимагає від майбутніх учителів початкової школи високого рівня компетенції, мобільності, здатності до інноваційного мислення, постійної самоосвіти й самовдосконалення, орієнтування в нестандартних ситуаціях та творче самостійне розв'язання їх. Функція сучасного педагога Нової української школи полягає в його вмінні організувати компетентнісне навчання («не знання заради знань, а вміння їх застосовувати в реальному житті, не що ти знаєш, а як ти цим умієш користуватися»), критично мислити, визначати власну позицію, бути орієнтованим на формування ключових і предметних компетентностей на всіх етапах молодших школярів (Концепція «Нова українська школа», 2016).

Сучасні ідеї трансформаційних змін в освіті XXI століття акцентують увагу на необхідності впровадження інновацій, спрямованих на формування творчого потенціалу і стимулювання мотивації студентів до саморозвитку. У закладах вищої освіти змінюються функції діяльності викладача (активно впроваджуються інноваційні технології, формується новий тип педагогічного мислення, в основі якого є розвиток конкурентоспроможного фахівця, здатність створювати комфортне студентоцентроване середовище), а також позиції студентів (ініціативність, вибір індивідуальної траєкторії навчання, уміння здійснювати особистісну й професійну рефлексію, умотивованість до самовдосконалення та нових педагогічних досягнень тощо).

Аналіз досліджень. Концептуальні положення щодо вдосконалення та подальшого розвитку вищої педагогічної освіти закладено у сучасних нормативних документах, зокрема законах України «Про освіту» (2017), «Про вищу освіту» (2014),
Національній стратегії розвитку освіти в Україні на період до 2021 року (2013), Концепції Нової української школи (2016), Концепції розвитку педагогічної освіти (2018), проєкті «Фінська підтримка реформи української школи» (2018), Професійному стандарті «Вчитель початкових класів закладу загальної середньої освіти» (2018) тощо.

Сучасні наукові розвідки свідчать, що проблему професійної підготовки майбутніх учителів початкової школи до організації інтерактивної навчальної взаємодії учнів різноаспектно розкрито в наукових дослідженнях (методологічні основи сучасної філософії освіти (В. Андрущенко, О. Базалук, В. Кремень, А. Кузьмінський, В. Луговий, В. Лутай, В. Огнев'юк та ін.); теоретико-практичні засади оновлення вищої педагогічної освіти в умовах євроінтеграції (К. Баханов, І. Богданов, I. Глазкова, О. Гуренко, В. Жигірь, А. Крамаренко, Л. Петухова, І. Соколова, О. Співаковський та ін.); особливості суб'єкт-суб'єктної педагогічної взаємодії викладачів і студентів (I. Андрощук, А. Бойко, Л. Велитченко, В. Гриньова, Н. Кічук, О. Легун та ін.), зокрема майбутніх учителів початкової школи (В. Бондар, О. Кіліченко, Л. Коваль, О. Ліннік, О. Матвієнко та ін.); реформування початкової освіти на ідеях Концепції Нової української школи (І. Барбашова, Н. Бібік, М. Вашуленко, Я. Кодлюк, О. Онопрієнко, О. Савченко, С. Скворцова, А. Цимбалару та ін.); застосування інтерактивних технологій навчання в освітньому процесі початкової школи (Л. Бєкірова, О. Комар, О. Ліба, І. Осадченко, Н. Павленко, Л. Пироженко, О. Пометун, Н. Руденко, Ю. Руднік та ін.)).

Отже, аналіз основних досліджень і публікацій під кутом зору порушеної проблеми засвідчує необхідність оновлення вищої педагогічної освіти на засадах гуманізації, студентоцентризму, співпраці, педагогіки партнерства, навчальної взаємодії на основі діалогу, що сприятиме налагодженню комфортних суб' єкт-суб'єктних стосунків між усіма учасниками освітнього процесу.

Мета статті полягає у вивченні реального стану підготовки майбутніх учителів початкової школи до організації інтерактивної навчальної 
взаємодії учнів та висвітленні перспектив втілення цього процесу у сучасній системі вищої педагогічної освіти.

Виклад основного матеріалу. Результати підготовки майбутніх учителів початкової школи значною мірою задекларовані в Професійному стандарті «Вчитель початкових класів закладу загальної середньої освіти». Так, у документі, що регламентує нормативну частину змісту педагогічної діяльності вчителя початкової школи, окреслено перелік умінь, які визначають його готовність до організації освітнього процесу в початковій школі, зокрема: складати план-конспект уроку 3 урахуванням предметної специфіки; відповідно до змісту конкретного уроку та рівня навчальних можливостей учнів добирати форми і методи, які будуть сприяти ефективному засвоєнню ними програмного матеріалу з метою організації інтерактивної навчальної взаємодії учнів; будувати суб'єкт-суб'єктні взаємини в класі на засадах дитиноцентризму, співпраці та ін. (Професійний стандарт, 2018).

Учитель початкових класів має володіти сучасними знаннями, зокрема, інноваційними методичними підходами, сучасними системами, методиками, технологіями навчання, розвитку й виховання молодших школярів; мати досвід застосовування їх на практиці; психолого-педагогічним інструментарієм, уміти застосовувати матеріальні й ідеальні засоби навчання, в тому числі й інтерактивні технології навчання; створювати сприятливі умови для організації міжособистісної взаємодії, успішно співпрацювати з колегами, учнями та їхніми батьками, в команді, групі. Знати механізми міжособистісного сприйняття (стереотипізація, рефлексія), стилі спілкування, характер комунікативних ситуацій і засоби їх вирішення, особливості міжособистісної взаємодії. Будувати партнерську взаємодію на основі морально-етичних та правових норм поведінки. Здатність бути критичним і самокритичним, наполегливим щодо поставлених завдань і взятих зобов'язань (Професійний стандарт, 2018).

У зв'язку із задекларованими в Професійному стандарті «Вчитель початкових класів закладу загальної середньої освіти» положеннями здобувачі першого (бакалаврського) рівня вищої освіти мають ефективно та адекватно здійснювати рефлексивні процеси, що сприяє розвитку й саморозвитку учнів, творчому підходу до освітнього процесу початкової школи, оцінювати результати педагогічних впливів та забезпечувати якість освітньої діяльності.

Окрім того, важливим для студентів спеціальності 013 «Початкова освіта» $є$ оволодіння дидактичною та методичною компетентністю.
Восновідидактичної компетентностієздатність майбутнього вчителя (випускника) вирішувати стандартні та проблемні професійні завдання, що виникають в освітній практиці початкової школи, на основі сформованих знань про особливості побудови змісту і процесу навчання молодших школярів, гнучкого володіння методами навчання; спроможність обгрунтовано вибирати прийоми, засоби, технології, форми організації освітнього процесу, адекватні дидактичній ситуації.

Методична компетентність грунтується на теоретичній і практичній готовності до проведення уроків за різними навчальними комплектами, що виявляється у сформованості системи дидактикометодичних знань і умінь із окремих розділів та тем курсу, окремих етапів навчання й досвіду їх застосування та наявності емоційно-ціннісного ставлення до діяльності щодо навчання учнів предмета.

У межах дидактико-методичної компетентності виокремимо перелік умінь, формування яких забезпечує готовність майбутніх учителів початкової школи до професійної діяльності, зокрема вміння здійснювати спочатку мікровикладання на основі суб'єкт-суб'єктної взаємодії учасників освітнього процесу, а потім моделювати, проводити й аналізувати уроки в початковій школі, організовуючи інтерактивну навчальну взаємодію на засадах педагогіки партнерства та співпраці.

3 метою вивчення реального стану підготовки майбутніх учителів початкової школи до організації інтерактивної навчальної взаємодії учнів розглянемо ресурсне забезпечення, а саме підручники та посібники, які активно використовують викладачі закладів вищої освіти в процесі фахової підготовки майбутніх учителів початкової школи. Наприклад, навчальна дисципліна «Дидактика», яка відіграє велику роль у професійному становленні майбутніх педагогів, розпочинає цикл фахових дисциплін, тому вважаємо за доцільне проаналізувати підручники таких авторів, як І. Барбашова, В. Бондар, Я. Кодлюк, О. Савченко та ін.

У підручнику «Дидактика» (2005) автор В. Бондар використовує інноваційну структуру дидактики як навчальної дисципліни і включає у iii зміст, крім традиційних, надпредметні знання (метазнання), так необхідні для реалізації нової функції підручника - конструктивно-продуктивної. Дидактика із суто теоретичної, інформаційно-повідомлюючої перетворюється на теоретико-прикладну, виконуючу роль філософії освіти й навчання, методології розроблення методик i технологій навчання. Цінність видання полягає в авторській позиції щодо питань теорії і прак- 
тики навчання дітей, підготовки вчителя сучасної школи. Вчений зазначає, що олюднення освітнього процесу відбувається не за рахунок знань учителя теорії і технології навчання, а завдяки його оволодінню (Бондар, 2005).

«Дидактика» В. Бондаря - один з перших підручників саме для вчителів початкової школи, де вчений доводить, що для педагога головним $є$ не просто грунтовні знання, а володіння технологіями навчання, педагогічною технікою - основою педагогічної майстерності. Відзначаючи фундаментальність праці, на нашу думку, автор не ставив за мету розкрити проблему, пов'язану 3 формуванням у майбутніх учителів уміння організовувати гуманістичну взаємодію, співпрацю, діалог. Наведені в підручнику приклади мають загальний характер і мало пов'язані 3 процесом навчання молодших школярів.

У навчальному посібнику «Дидактика» (2011) автор I. Барбашова розкриває важливі питання теоpiї освіти і навчання. Його метою $є$ забезпечення засвоєння студентами теоретичних основ дидактики, розвиток у майбутніх фахівців критичного педагогічного мислення, виховання професійно значущих рис особистості. Змістове наповнення дає змогу сформувати уявлення про дидактику як галузь педагогічної науки; розкрити культурологічну спрямованість шкільної освіти; ознайомити із сутністю процесу навчання з позиції партнерства всіх його учасників, що здійснюється через аналіз суб'єкт-суб'єктної взаємодії викладання й учіння; охарактеризувати принципи та правила навчання, які відображають зовнішні та внутрішні його зв'язки і регулюють практичні дії вчителя та учнів; 3'ясувати сутність, функції та класифікації методів навчання, види та особливості їх застосування в процесі навчання дидактичних засобів; проаналізувати організаційні форми навчання, характеристику уроку, види навчально-пізнавальної діяльності учнів на уроці, перевірку успішності, специфіку позаурочних форм навчання; дозволяє виявити теоретичні засади провідних технологій навчання (Барбашова, 2011). Не применшуючи важливості проаналізованого навчального посібника, слід зазначити, що авторка не досить уваги приділяе прикладам, які стосуються безпосередньо вдосконалення освітнього процесу в початковій школі. Усе це свідчить про брак відомостей, які мають стати теоретичним підгрунтям для організації дитиноцентрованого навчання, суб'єкт-суб'єктної взаємодії.

Основне призначення навчально-методичного посібника «Дидактика початкової школи: практичний курс» (2013) за авторством Я. Кодлюк полягає в ознайомленні майбутніх педагогів 3 тео- ретичними засадами організації освітнього процесу в школі, зокрема початковій ланці; розкритті особливостей діяльності вчителя та учнів у цьому процесі; поглибленні знань студентів про форми, методи та засоби навчання школярів та формуванні в них загальнонавчальних умінь і навичок, які охоплюють організаційні вміння (організовувати робоче місце, точно виконувати вказівки дорослого, планувати навчальні дії), загальномовленнєві (слухати, відповідати, запитувати, міркувати), загальнопізнавальні (спостерігати, аналізувати, порівнювати, узагальнювати) та контрольно-оцінні (орієнтуватись на зразок, здійснювати само- і взаємоконтроль, висловлювати оцінні судження). Викликають інтерес розроблені автором тестові завдання для перевірки засвоєння студентами знань 3 проблеми загальнонавчальних умінь і навичок, а також способів їх практичного застосування майбутніми вчителями початкової школи. Однак за наявності всіх позитивних моментів цього видання хотілося б зазначити, що вчена не надає належної уваги вирішенню питання щодо формування в педагогів готовності до організації інтерактивної навчальної взаємодії молодших школярів як у теоретичному, так і практичному аспектах (Кодлюк, 2013).

Особливо зазначаємо сучасність підручника «Дидактика початкової освіти» (2012) О. Савченко, оскільки основною ідеєю його $є$ впровадження особистісно орієнтованого підходу, гуманізація навчання молодших школярів й уміння педагогів створювати сучасне освітнє середовище. Матеріал, дібраний у підручнику, знайомить студентів 3 інтерактивними технологіями навчання, умовами організації суб'єкт-суб'єктної взаємодії, акцент зроблено на інноваційних формах і методах, зразках побудови уроків. Значну увагу приділено усвідомленню майбутніми вчителями початкової школи особливостей розвитку нового типу педагогічного мислення, центрованого на інтересах учнів. Авторка не лише наводить перелік загальнонавчальних умінь i навичок, відповідно до навчальних програм для початкової школи (організаційні, загальномовленнєві, загальнопізнавальні й контрольно-оцінні), але й пропонує практичні рекомендації з їх формування в освітньому процесі початкової школи. Вчена наголошує на значущості розвитку в молодших школярів ключової компетентності - вміння вчитися (Савченко, 2012).

Отже, зазначимо, що проаналізовані навчальні видання $\epsilon$ вагомим внеском у фахову підготовку студентів спеціальності 013 «Початкова освіта», проте, на нашу думку, формування у майбутніх учителів початкової школи готовності до орга- 
нізації інтерактивної навчальної взаємодії учнів вони не забезпечують повною мірою. Тому викладачам закладів вищої освіти необхідно активніше долучитися до розроблення практичного складника, де будуть передбачені спеціальні практикоорієнтовані завдання 3 підготовки до такого виду діяльності - здатності організовувати інтерактивну навчальну взаємодію учнів у реальному освітньому процесі початкової школи.

Далі проаналізуємо наукові джерела, що рекомендовані для методичної підготовки майбутніх учителів початкової школи під кутом зору досліджуваної проблеми.

Авторка посібника «Методика читання у початкових класах» (2007) О. Савченко у вступному слові визначає концепцію сучасної методики: «не предметоцентризм, а дитиноцентризм. Нова школа, сім'я чекають на вчителя, який не тисне на дитину, а співпрацює, будує навчання на діалозі i партнерських відносинах, утверджує людську гідність кожного вихованця». Важливо, що вчена передбачає завдання, які сприяють індивідуалізації читацької діяльності учнів: застосування диференційованих завдань на уроці і для домашньої роботи, завдань на вибір, індивідуального підходу в оцінюванні темпу і виразності читання та інше. В аналізованому посібнику звертається увага вчителя на те, що він має сформувати мовну особистість учня 3 достатніми комунікативними можливостями, мотивацію до самостійного читання, спілкування 3 найкращими дитячими книгами.

Навчальний посібник «Методика читання» (2010) авторів Г. Коваль, Л. Іванова, Т. Суржук розкриває основні аспекти формування мовленнєвої компетентності учнів (читати і розуміти текст; вести діалог; сприймати, відтворювати і створювати усні й писемні монологічні та діалогічні висловлювання різних видів, типів і жанрів; брати участь у дискусіях; переконувати і відстоювати свою точку зору; висловлювати власні думки, міркування, погляди), необхідні учням у різноманітних життєвих ситуаціях; користуватися усною й писемною літературною мовами, багатством iï виражальних засобів залежно від мети і завдань висловлювання. Колектив авторів пропонує систему завдань для формування відповідних умінь і навичок учнів. При цьому перевага надається інтерактивним педагогічним ситуаціям, рольовим іграм, коли кожен учень має можливість висловитись, проявити себе в комунікативному процесі.

Підручник «Методика навчання української мови в початковій школі» (2011) за редакцією М. Вашуленка висвітлює особливості складної та багатоаспектної роботи вчителя над мовно- літературною освітньою галуззю в початковій школі. Майбутні педагоги мають можливість здобути грунтовну теоретичну підготовку щодо організації спілкування 3 дітьми, застосовуючи діалогічну та полілогічну форми, дискусії, групові види роботи; оволодіти різними засобами підвищення уваги та працездатності учнів, мотивування їх до навчально-пізнавальної діяльності, яка потребує активної мовленнєвої вправності, що передбачає орієнтацію на всі ії чотири види: слухання і розуміння (аудіювання), говоріння, читання і письмо та ін. Підручник, на нашу думку, $\epsilon$ сучасним і важливим у підготовці вчителя до моделювання уроків різних типів, що вирізняє його 3-поміж інших методичних праць. Проте, на жаль, особливого значення автори не приділяють підготовці студентів до організації інтерактивної навчальної взаємодії учнів на уроці.

Матеріали посібника «Українська мова 3 методикою навчання в початкових класах: інтегрований курс» (2011) за загальною редакцією А. Каніщенко, Г. Ткачук зосереджують увагу на успішному розвитку мовлення молодших школярів не лише в теоретичному, а й практичному аспектах. Головне завдання інтегрованого курсу полягає у формуванні творчого педагога 3 якісно іншим педагогічним мисленням, який навчив би учнів не тільки засвоювати знання 3 різних освітніх галузей початкової школи, а й висловлювати власні думки. На нашу думку, аналізована навчальна праця значно б виграла, якби вчені більше приділили уваги розумінню педагогами важливості організації ефективного спілкування, вмінню молодших школярів логічно доводити свою думку, критично оцінювати інших на основі діалогічного спілкування, взаємодопомоги.

Одним 3 важливих складників ресурсного забезпечення підготовки майбутніх учителів початкової школи є шкільні підручники з різних освітніх галузей, у тому числі й розроблені на впровадженні ідей Концепції Нової української школи, які здебільшого орієнтовані на формування в молодших школярів умінь взаємодіяти, співпрацювати, вступати в діалог, висловлювати власну думку, враховуючи позиції інших. Отже, проаналізуємо деякі з них. Так, підручник М. Захарійчук «Українська мова. Буквар: у 2-х частинах» (2018) для 1-го класу закладів загальної середньої освіти містить контент, який відображає змістову реалізацію компетентнісного підходу, зокрема, спрямований на розвиток мовленнєвої креативності молодшого школяра. Суттєвою, на нашу думку, $\epsilon$ діяльнісна основа підручника, підпорядкована принципам дитиноцентрованості, природовідпо- 
відності, науковості, доступності, логічної послідовності, що є потенціалом для формування в учнів наскрізних умінь, предметних і ключових компетентностей. Інтегрований зміст підручника - цілісна система усних видів мовленнєвої діяльності (слухання - розуміння, говоріння, читання вголос і мовчки, робота 3 дитячою книжкою, письмові види роботи), які взаємопов'язані в цільовому, змістовому, процесуальному й результативно-прогностичному аспектах.

Підручник інтегрованого курсу Г. Остапенко «Українська мова та читання» (2019) для 2-го класу поєднує розкриття всіх змістових ліній мовно-літературної галузі Державного стандарту початкової школи. Авторка акцентує увагу на тому, що учні, читаючи та обговорюючи літературні твори, співпрацюючи в парах, групах, усім класом, залучаються до виконання завдань на спостереження за мовленням, вчаться самостійно робити висновки та формулювати їх на основі взаєморозуміння, взаємодопомоги, позитивного ставлення один до одного.

Аналіз підручника О. Савченко «Літературне читання» (2013) для 3-го класу закладів загальної середньої освіти дозволяє простежити, що він спрямований на пізнання учнями навколишньої дійсності, розвиток естетичних та етичних почуттів, творчих уподобань. На уроках молодші школярі збагачують, уточнюють, активізують свій словник; у них формуються вміння висловлюватись усно і письмово, вдумливо читати, здатності до творчості, яка розглядається як загальнолюдська цінність. На сторінках підручника вчена особливу увагу приділяє завданням до текстів, у результаті виконання яких учні здобувають уміння вести діалог, співпрацювати в парах і групах, а вчитель виступає координатором такої діяльності. Таке подання матеріалу в підручнику є свідченням розуміння авторкою пріоритетності інтерактивної навчальної взаємодії молодших школярів на уроках читання різних типів, що важливо для нашого дослідження.

Аналізуючи підручник В. Науменко «Літературне читання» (2015) для 4-го класу загальноосвітніх навчальних закладів, зазначаємо, що він побудований на основі двох принципів: художньо-естетичного i літературознавчого. Голо- вну мету підручника авторка вбачає у формуванні читацької компетентності молодших школярів, що $є$ базовим складником комунікативної і пізнавальної, в ознайомленні учнів 3 дитячою літературою як мистецтвом слова, у підготовці їх до систематичного вивчення курсу літератури в основній школі як засобу успішної реалізації та саморозвитку особистості учня. На нашу думку, використання традиційних методів і прийомів, на що акцентована увага аналізованого підручника (прагнення дізнатись про життя людей, ознайомлення 3 подіями, вчинками героїв, які відбуваються в часі, тощо), замало для організації ефективної співпраці, суб'єкт-суб'єктної взаємодії учасників освітнього процесу.

Висновки. Аналіз стану досліджуваної проблеми засвідчив, що у сучасних стратегічних орієнтирах професійної підготовки майбутніх учителів початкової школи ще не досить уваги приділено реалізації масштабної реформи освіти «Нова українська школа». У змісті теоретичної та практичної підготовки фахівців першого (бакалаврського) рівня вищої освіти спеціальності 013 «Початкова освіта» передбачено замало практико-орієнтованих завдань, які б сприяли формуванню у них умінь створювати комфортне освітнє середовище в початковій школі, забезпечувати діалогову взаємодію; моделювати, проводити та аналізувати уроки на основі організації інтерактивної навчальної взаємодії молодших школярів. Проте принагідно зауважимо, що сучасна початкова школа в цьому плані є більш підготовленою і загалом має відповідне ресурсне забезпечення, яке дозволяє майбутнім педагогам якісно підготуватися до моделювання й проведення уроків 3 використанням інноваційних технологій, в основі яких є суб'єкт-суб'єктна навчальна взаємодія, діалог, співпраця та співтворчість. Тож вважаємо за потрібне зосередити увагу викладачів закладів вищої освіти на значущості та активному використанні у процесі навчання студентів саме шкільних підручників, що в комплексі забезпечить результативність їх професійної підготовки.

Перспективи подальших розвідок вбачаємо у вивченні проблем підготовки майбутніх учителів початкової школи на засадах педагогіки партнерства в умовах розбудови Нової української школи. 


\section{СПИСОК ВИКОРИСТАНИХ ДЖЕРЕЛ}

1. Барбашова I. А. Дидактика : навчальний посібник для студентів вищих навчальних закладів. 2-ге вид., випр., доп. Донецьк : ЛАНДОН-ХХІ, 2011. 228 с.

2. Бондар В. І. Дидактика : підручник для студентів вищих педагогічних навчальних закладів. Київ : Либідь, 2005. $264 \mathrm{c}$.

3. Коваль Л., Попова О., Нестеренко М. Трансформаційні зміни в професійній підготовці майбутніх педагогів у контексті впровадження ідей Концепції Нової української школи. Наукові записки Бердянського державного педагогічного університету. Серія: Педагогічні науки : зб. наук. пр. Бердянськ : БДПУ, 2020. Вип. 1. С. 304-312.

4. Кодлюк Я. П. Дидактика початкової школи: практичний курс : навчально-методичний посібник. Тернопіль : Астон, 2013. 160 с.

5. Концепція Нової української школи. МОН України. 2016. URL: https://mon.gov.ua/storage/app/media/zagalna\% 20serednya/nova-ukrainska-shkola-compressed.pdf (дата звернення: 19.10.2020).

6. Про затвердження Професійного стандарту «Вчитель початкових класів закладу загальної середньої освіти» : Наказ Міністерства соціальної політики України № 1143 від 10.08.2018 року. Освіта в Україні. URL: http://osvita.ua/ legislation/Ser_osv/61635/ (дата звернення: 27.10.2020).

7. Савченко О. Я. Дидактика початкової освіти : підручник. Київ : Грамота, 2012. 504 с.

\section{REFERENCES}

1. Barbashova, I. A. (2011). Dydaktyka: navch. posib. dlia stud. vyshch. navch. zakl., 2-he vyd., vypr., dop. [Didactics: educational manual for students of higher educational institutions, second edition, corrected, supplemented]. Donetsk: LANDON-XXI, $228 \mathrm{~s}$. [in Ukrainian].

2. Bondar, V. I. (2005). Dydaktyka: pidruchnyk dlia stud. vyshch. ped. navch. zakl. [Didactics: a textbook for students of higher pedagogical educational institutions]. Kyiv: Lybid, 264 s. [in Ukrainian].

3. Koval, L., Popova, O., Nesterenko, M. (2020). Transformatsiini zminy v profesiinii pidhotovtsi maibutnikh pedahohiv u konteksti vprovadzhennia idei Kontseptsii Novoi ukrainskoi shkoly. Naukovi zapysky Berdianskoho derzhavnoho pedahohichnoho universytetu. Seriia: Pedahohichni nauky: zb. nauk. pr. [Transformational changes in the professional training of future teachers in the context of implementing the ideas of the Concept of the New Ukrainian School. Scientific notes of Berdyansk State Pedagogical University. Series: Pedagogical sciences: a collection of scientific works]. Berdiansk: BDPU, Vyp. 1. S. 304-312 [in Ukrainian].

4. Kodliuk, Ya. P. (2013). Dydaktyka pochatkovoi shkoly: praktychnyi kurs : navch.-metod. posib. [Didactics of primary school: a practical course: educational and methodical manual]. Ternopil: Aston, $160 \mathrm{~s}$. [in Ukrainian].

5. Kontseptsiia Novoi ukrainskoi shkoly (2016). MON Ukrainy. [The concept of the New Ukrainian School. Ministry of Education and Science of Ukraine]. URL: https://mon.gov.ua/storage/app/media/zagalna\%20serednya/nova-ukrainska-shkola-compressed.pdf [in Ukrainian].

6. Ppo zatverdzhennia Profesiinoho standartu "Vchytel pochatkovykh klasiv zakladu zahalnoi serednoi osvity" (2018): Nakaz Ministerstva sotsialnoi polityky Ukrainy No. 1143 vid 10.08.2018 roku. Osvita v Ukraini. [About approval of the Professional Standard "Primary School Teacher of General Secondary Education": Order of the Ministry of Social Policy of Ukraine No. 1143 dated August 10, 2018. Education in Ukraine]. URL : http://osvita.ua/legislation/Ser_osv/61635/ [in Ukrainian].

7. Savchenko, O. Ya. (2012). Dydaktyka pochatkovoi osvity: pidruchnyk. [Didactics of primary education: a textbook]. Kyiv: Hramota, 504 s. [in Ukrainian]. 